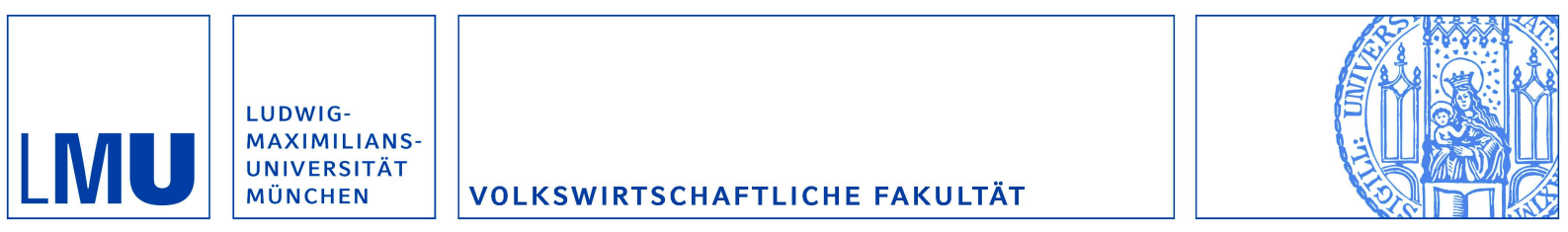

Fidrmuc, Jarko; Horváth, Roman und Horváthová, Eva:

Corporate Interest Rates and the Financial Accelerator in the Czech Republic

Munich Discussion Paper No. 2008-23

Department of Economics

University of Munich

Volkswirtschaftliche Fakultät

Ludwig-Maximilians-Universität München

Online at https://doi.org/10.5282/ubm/epub.7191 


\title{
Corporate Interest Rates and the Financial Accelerator in the Czech Republic ${ }^{*}$
}

\author{
Jarko Fidrmuc $^{\mathrm{I}}$ \\ University of Munich; CESifo; and Comenius University Bratislava \\ Roman Horváth ${ }^{\text {II }}$ \\ Czech National Bank and Institute of Economic Studies, Charles University \\ Eva Horváthová ${ }^{\text {III }}$ \\ European Privatization and Investment Corporation and Charles University, Faculty of \\ Humanities, Prague
}

November 2008

\begin{abstract}
We analyze the determinants of the corporate interest rates and the financial accelerator in the Czech Republic. Using a unique panel of 448 Czech firms from 1996 to 2002, we find that selected balance sheet indicators influence significantly the firm-specific interest rates. In particular, debt structure and cash flow have significant effects on interest rates, while indicators on collateral play no significant role. We find evidence that monetary policy has stronger effects on smaller firms than on medium and larger firms. Finally, we find no asymmetric effects in the monetary policy over the business cycle.
\end{abstract}

JEL Classification: E43, E32, G32, C23.

Keywords: Monetary policy transmission; balance sheet channel; financial accelerator; corporate interest rates. Running Title: Corporate Interest Rates in the Czech Republic

\footnotetext{
*We appreciate comments by Martin Cincibuch, Christa Hainz, and other seminar participants at the Czech National Bank, University of Munich and University of Rome - Tor Vergata. Karl Oorloff provided excellent research assistance. The financial support from the Institute of Economic Studies, Charles University (Institutional Research Framework 2005-2010, MSM0021620841) is gratefully acknowledged. The views expressed here do not necessarily represent those of the Czech National Bank.

${ }^{\text {I }}$ Department of Economics, University of Munich, Geschwister-Scholl-Platz 1, 80539 Munich, Germany, Tel.: +49 892180 5544, Fax: +49 89218016463 e-mail: jarko.fidrmuc@lrz.uni-muenchen.de.

${ }^{\text {II }}$ Czech National Bank, Na Prikope 28, 11503 Prague 1, Czech Republic, Phone: 0042022442 1111, Fax: 0042022421 8522, e-mail: roman.horvath@cnb.cz.

${ }^{\text {III }}$ Charles University, Faculty of Humanities, Prague, U Krize 8, 15600 Praha 5, Czech Republic, e-mail: ev.horvathova@gmail.com.
} 


\section{Introduction}

The effects of monetary policy depend crucially on the properties of the transmission mechanism (see Elbourne and de Haan, 2006). Therefore, an accurate understanding of monetary policy transmission is a key precondition for an efficient implementation of the monetary policy. While there is considerable empirical evidence on the monetary policy transmission mechanism in the euro area (see Angeloni et al., 2003), there is insufficient research regarding the transmission mechanism in the European Union's new member states. This is striking for various reasons, especially considering that many of these economies are likely to join the euro area. This lack of information is especially pertinent at the microeconomic level and for specific channels of monetary transmission. For example, a comprehensive survey by Coricelli et al. (2006) does not identify a single study on the balance sheet channel in Central and Eastern Europe.

Consequently, this paper aims to bridge this gap by providing empirical evidence on the balance sheet channel in the Czech Republic. ${ }^{1}$ More specifically, we aim to provide empirical evidence on whether the impact of monetary policy on corporate interest rates (controlling for balance sheet indicators) depends on the size of firms or business cycle. Such evidence is scarce for developed countries, too. Benito and Whitley (2003) analyze the determinants of corporate interest rates, but do not investigate whether monetary policy propagates unequally across firms. Mojon et al. (2002) study the propagation of monetary policy effects according to firm size, but their specification does not focus on the role of balance sheet indicators. Although the business cycle in the Czech Republic is characterized by mainly idiosyncratic developments (see Fidrmuc and Korhonen, 2006) some findings presented here may also provide a benchmark for additional new member states.

The paper is organized as follows. Section 2 presents a short review on transmission mechanisms, especially in the euro area and in the new member states. Section 3 provides a description of our dataset and presents descriptive statistics for selected variables. In Section 4 , we present regression analysis on determinants of corporate interest rates and the financial accelerator. We conclude in Section 5. Finally, the Appendix contains details on the construction of the variables.

\footnotetext{
${ }^{1}$ For general overview of Czech monetary policy, see Kotlan and Navratil (2003) and Fidrmuc (2008).
} 


\section{Literature Review}

Given the assumption of imperfect capital markets (in view of information asymmetries and contract enforcement problems), there is a wedge between the costs of internal and external financing. The balance sheet channel links the cost of external finance to the financial position of the borrower. ${ }^{2}$ In response to a negative demand shock, firms' internal sources of funding typically worsen and the firms become more dependent on external finance. However, at the same time, the cost of external financing tends to increase as the financial health of a borrower weakens. A greater dependence on external funding at a time when the cost of borrowing has increased has been characterized as a "financial accelerator effect" (Bernanke et al., 1999). Consequently, corporate financial positions-balance sheet strength-amplify output fluctuations (Bernanke and Gertler, 1989).

According to Gertler and Gilchrist (1993), monetary policy might have asymmetric effects over the business cycle. Thus, interest rate changes are more powerful during the downturns than during the boom periods. ${ }^{3}$ In addition, Gertler and Gilchrist (1994) and Oliner and Rudebush (1996) suggest that monetary policy shocks have stronger effects on smaller firms than on larger firms as a result of unequal access to external financing. Boissay (2001) suggests that financial accelerator effects might be particularly strong during the periods of credit rationing. As a result, financial accelerator theory may be especially relevant in recent days of global financial crisis.

The majority of econometric studies investigating the financial accelerator analyze corporate investment dynamics (see Vermeulen, 2002, and Berg et al., 2004), while only few studies have focused on the determinants of corporate interest rates within the financial accelerator framework. Mojon et al. (2002) analyze corporate interest rate dynamics in the four largest euro-area countries in an error-correction framework. They find that firm characteristics influence the interest rates firms are charged. In contrast to our results, they find little evidence that monetary policy in these countries has a heterogeneous impact on firms and also on the business cycle. Benito and Whitley (2003) study the factors affecting the corporate interest rates in the United Kingdom in a dynamic setting. Their results indicate that firms'

\footnotetext{
${ }^{2}$ Calstrom and Fuerst (1997), Kiyotaki and Moore (1997), Bernanke et al. (1999), and Moons and Van Poeck (2008) model the interactions between borrowing costs and the financial position of borrower.

${ }^{3}$ See also Kashyap et al. (1994) and Gazioglu and McCausland (2008). Another stream of literature analyses the asymmetric effects of monetary policy and the role of downward price rigidity (see, for example, Ball and Mankiw, 1994). Nevertheless, the recent empirical evidence from the euro area countries rather contradicts the hypothesis of the downward price rigidity (see Dhyne et al., 2005).
} 
balance sheets are indeed an important determinant of corporate interest rates.

From the perspective of transition economies, several papers analyze the corporate investment dynamics (see for example Lizal and Svejnar, 2002, Konings et al., 2003, and Hanousek and Filler, 2004, for the Czech Republic). In general, these studies examine the role of ownership, credit rationing, and the soft-budget constraints. While they provide important insights into the nature of Czech firms' investment dynamics, they do not focus on the heterogeneity in firms' responses to monetary policy shocks and typically employ data from the mid-1990s. More recently, Pruteanu (2004) analyzes whether banks have rationed credits to the enterprises in the Czech Republic between 1997 and 2002. However, this stream of literature does not focus on whether monetary policy propagates unequally across firms or over business cycle.

Pruteanu-Podpiera (2007) and Schmitz (2004) analyze potential monetary policy heterogeneity in transition countries at the micro level. However, both studies focus on the bank lending channel, while we aim to complete the earlier results with our evidence on the importance of balance sheet channel in the Czech Republic. Pruteanu-Podpiera (2007) finds that monetary policy affects the growth rate of loans and that the link has gained in importance during the analyzed period (1996 to 2001). In addition, the results show certain evidence that monetary policy has heterogeneous effects on bank lending. Similarly, Schmitz studies the role of banks in monetary policy transmission in several new EU members between 1990 and 2001. These results show that the bank's lending reacts significantly to the monetary policy tightening. In turn, she finds no evidence of heterogeneity in monetary policy transmission.

Thus, the current empirical evidence on the heterogeneity of monetary policy shocks is rather ambiguous. We try to provide further evidence on this issue. Anticipating our results, we find that small firms are stronger influenced by the monetary policy changes, while there is no significant evidence on differences in the balance sheet channel of the monetary transmission during the economic cycle. ${ }^{4}$

\section{Data Description}

We exploit unique company records compiled by the Čekia Agency, which is a Czech provider of business information services. The applied data is part of their Magnus data set,

\footnotetext{
${ }^{4}$ However, this finding can be influenced by the fact that our time coverage is six years, which may not be sufficient to fully assess the impact of cyclical activity.
} 
which was not previously used in the literature. The original unbalanced panel data set incorporates the annual financial statements of 461 non-financial companies between 1993 and 2002. Full balance sheets and profit and loss accounts are available for each individual firm. The data set also contains a detailed description of the economic activity of each firm and dummies for fifteen industries. ${ }^{5}$

We performed several consistency tests of the individual data before further work. In particular, we checked whether selected ratios (for instance the ratio of liquid assets to assets or of debt to assets) lie between zero and one. Nevertheless, we excluded only six firms from the sample, which confirms the high quality of the data set.

Although the original data set starts in 1993, there are only a few (11 firm records) observations until 1995. Therefore, we use only company records from 1996 to 2002, and the majority of observations are from 1999 to 2002. While the data set for 1996, 1997, and 1998 contains 17, 39, and 81 firms, respectively, the number of firms for 1999-2002 exceeds 300 in each year. ${ }^{6}$ In total, the unbalanced sample accounts for 1494 observations from 448 firms. On average, we have at least three subsequent years for a given firm.

Using the available information, we compute the implicit corporate interest rate, $I R$, for the firm $i$ at time $t$ as

$$
I R_{i t}=\frac{I N R E X_{i t}}{T D E B T_{i t}}
$$

where INREX denotes the interest expenses from the profit-loss account, and $D E B T$ stands for total debt defined as a sum of fixed liabilities, bank loans and borrowings from the balance sheet.

However, Benito and Whitley (2003) criticize this measure of corporate interest rates. They argue that this measure based on year-end balance sheets may be "artificially" high if a firm reduces the amount of its debt substantially in the course of a financial year. To address the empirical relevance of this issue, we examine a correlation of our measure of interest rates and aggregate interest rates. In addition, we exclude possible outliers (defined as 5 percent of the lowest and highest interest rates) in sensitivity analyses (not reported here). The empirical

\footnotetext{
${ }^{5}$ The industries include agriculture, food production, beverage and tobacco production, mining and processing of minerals and ors, textile and leather production, wood processing and paper production, chemical and pharmaceutics and rubber production, construction, metallurgy, machine building, electronics, power engineering, transportation, commerce, and glass and pottery.

${ }^{6}$ We use annual dummies to control for possible differences between the sub-samples in sensitivity analysis, which yield the same results (available upon request from authors).
} 
results suggest that this issue is only of limited relevance in our sample.

For the comparison of implicit corporate interest rates with the total aggregate, we use the ARAD public database operated by the Czech National Bank (CNB). This data set includes the debt outstanding and interest rates. Both variables are reported according to the maturity, as short, medium or long term (see Appendix for details).

Figure 1: Aggregate and Corporate Interest Rates in the Czech Republic

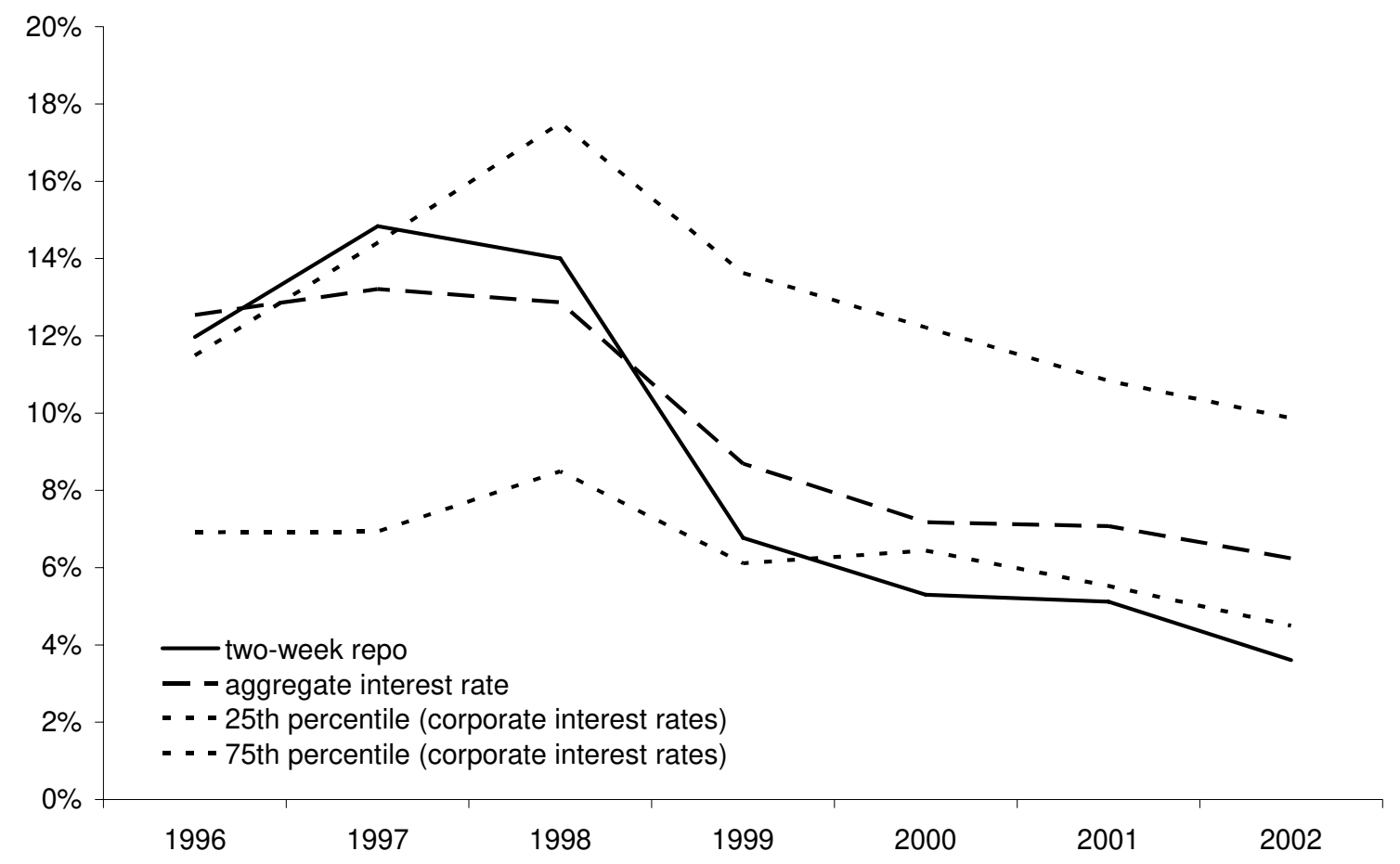

The adequacy of our measure of a sample corporate interest rate is examined in Figure 1. We compare this interest rate with the aggregate interest rate. The aggregate interest rates are calculated as the weighted average of inter-bank interest rates according to their maturity (see Appendix for details on construction) with weights determined by the amount of respective outstanding loans. Figure 1 shows that the sample interest rates are well correlated with the aggregate interest rates, which follow the development of the policy rate (two-week repo). The single exception is the first available year in our sample, which has a low number of observations (17 firms). This may lower especially the upper bound of implicit corporate rates. Nevertheless, this does not influence later results.

Furthermore, Figure 1 also presents the distribution of the corporate interest rates as it shows interest rates for the $25^{\text {th }}$ and $75^{\text {th }}$ percentiles. It provides evidence of considerable firm 
heterogeneity concerning interest rates charged by banks. Additionally, it seems the crosssectional variation in interest rates depends on the mean corporate interest rate. We can see that the variation of corporate interest rates increases when the interest levels are higher. Thus, the firm heterogeneity tends to increase during a downturn. It suggests that credit conditions worsen more than proportionally for certain firms during the downturns. For instance, the corporate interest rate at the $25^{\text {th }}$ percentile stands at around 7 percent and increases to 8 percent during the downturn, while the corresponding increase at the $75^{\text {th }}$ percentile is from 12 percent to 18 percent. These findings comply with Benito and Whitley (2003) for the United Kingdom.

Despite possible critique, the obvious advantage of using corporate interest rates is that they provide rich cross-sectional information, which is otherwise hardly available. Table 1 presents descriptive statistics of selected firm-specific indicators. In addition to the whole sample, we also report sub-samples according to different company size (identified as the lower, medium and upper third of the firms according to their assets) and downturns (negative GDP growth rates, which were reported for 1997 and 1998) or recoveries (positive GDP growth rates denoted as booms in Table 1). Generally, the corporate interest rates are broadly related to the firm size, although we can see large standard deviation of interest rates as well. Furthermore, interest rates are also higher during the downturn periods than during the recoveries. The balance sheet indicators also differ across firm size. Interestingly, the indicators seem to worsen only marginally during the downturns.

Table 1: Descriptive Statistics for Selected Balance Sheet Indicators

\begin{tabular}{lcccccc}
\hline & $\begin{array}{c}\text { Small } \\
\text { firms }\end{array}$ & $\begin{array}{c}\text { Medium } \\
\text { firms }\end{array}$ & $\begin{array}{c}\text { Large } \\
\text { firms }\end{array}$ & Downturns & Recoveries & Total \\
\hline Corporate interest rates & 12.04 & 9.67 & 8.86 & 12.88 & 10.02 & 10.25 \\
& $(10.17)$ & $(7.05)$ & $(8.08)$ & $(7.76)$ & $(8.8)$ & $(8.75)$ \\
Net debt to assets & 0.20 & 0.25 & 0.26 & 0.27 & 0.24 & 0.24 \\
& $(0.17)$ & $(0.21)$ & $(0.22)$ & $(0.16)$ & $(0.2)$ & $(0.2)$ \\
Debt structure & 0.22 & 0.27 & 0.32 & 0.28 & 0.27 & 0.27 \\
& $(0.23)$ & $(0.27)$ & $(0.29)$ & $(0.26)$ & $(0.27)$ & $(0.27)$ \\
Cash flow to assets & 0.06 & 0.06 & 0.07 & 0.04 & 0.06 & 0.06 \\
& $(0.1)$ & $(0.14)$ & $(0.15)$ & $(0.09)$ & $(0.14)$ & $(0.13)$ \\
Collateral to assets & 0.31 & 0.34 & 0.39 & 0.4 & 0.34 & 0.35 \\
& $(0.15)$ & $(0.16)$ & $(0.17)$ & $(0.18)$ & $(0.16)$ & $(0.16)$ \\
No. of observations & 498 & 498 & 498 & 120 & 1374 & 1494 \\
\hline
\end{tabular}

Note: See Appendix for details on construction of variables. Standard deviations are in parentheses. 


\section{Determinants of Corporate Interest Rates}

\subsection{Overall Results}

We start with a general analysis of determinants of corporate interest rates. In particular, we link the corporate interest rates to selected financial ratios, which show the extent of leverage, liquidity, market access, and collateral value. These variables have been identified in the literature as the most influential determinants of corporate interest rates (see for example, Benito and Whitley, 2003 or Mojon et al. 2002). Furthermore, we include a dummy for small firms and for the downturn periods. First, we estimate the equation (2) linking the balance sheet indicators to corporate interest rates:

$$
I R_{i t}=\alpha_{1} \frac{D E B T_{i t}}{A_{i t}}+\alpha_{2} \frac{C F_{i t}}{A_{i t}}+\alpha_{3} D S T R_{t t}+\alpha_{4} D O W N_{t}+\alpha_{5} S_{i}+u_{i}+e_{i t}
$$

The dependent variable, $I R$, represents the corporate interest rate of the $i$-th firm at time $t$, computed from the firm's financial statements (as the ratio of interest rate expenses to total debt). $D E B T$ is the company net debt. The cash flow denoted by $C F .^{7}$ The variables $D E B T$ and $C F$ are normalized by firm's assets, $A$. The debt structure is captured by DSTR, which is defined as one minus the ratio of short-term debt to total debt. This variable serves as a proxy for assessing the degree of market access for firms (see Bougheas et al., 2006, i.e. the extent of short-term debt financing). The dummy variable DOWN captures whether the Czech Republic experiences aggregate negative growth rates in time $t$. The variable $S$ is a dummy to assess whether small firms face different (mainly higher) interest rates. Furthermore, $u_{i}$ is an unobserved firm fixed effect, and $e$ is the error term. A detailed definition of the variables is presented in Appendix.

In general, more leveraged firms are more likely to default (see Fidrmuc et al., 2006), and thus the lenders seek to be compensated by higher interest rates. Hence, $\alpha_{1}$ is expected to yield a positive sign. The sign of $\alpha_{2}$ should be negative as more liquid firms are likely to be charged lower interest rates. Furthermore, risky projects are unable to receive the long-term finance and are thus forced to finance their projects with short-term debt (see Bougheas et al., 2006). Thus, $\alpha_{3}$ is expected to be negative.

In addition to firm specific data, macroeconomic development is also expected to influence

\footnotetext{
${ }^{7}$ An alternative indicator of liquidity is the ratio of liquid assets to assets. In our sample, the correlation of liquid assets and cash flow (both normalized by assets) is 0.76 . Therefore, we do not report the results with liquid assets, as the results are qualitatively similar.
} 
corporate interest rates. In particular, we expect $\alpha_{4}$ to be positive for several reasons. Banks may, for example, contract their lending during a downturn. Similarly, $\alpha_{5}$ is likely to be positive, because small firms are more risky and may entail greater agency costs for borrowers (see Bernanke and Gertler, 1989).

Although we performed dynamic panel data estimators using the Arellano-Bond GMM estimator, which is often used in the literature, we do not report these results for two reasons: First, if applied, the number of observations reduces to about one-third because the time dimension of our sample is rather short. Second, the lagged dependent variable is insignificant in all the specifications we estimated (not presented here). Also, dynamic panel data estimators applied samples with short time dimension are likely to be biased (see Nerlove, 2002). Consequently, the estimation of (2) is based on the static panel data models accounting for the endogeneity of regressors. As instruments, we use industry and time dummies. While industry dummies may capture different risks of industries, time dummies may reflect underlying macroeconomic effects. ${ }^{8}$

We present the fixed effect estimations of determinants of corporate interest rates in Table 2. ${ }^{9}$ The results suggest that the debt structure is a particularly robust determinant of corporate interest rates. Furthermore, we also find certain evidence that the leverage and liquidity indicators influence the corporate interest rates, but both net debt and cash flow become insignificant if we include all variables in the regression.

Firms with higher collateral values are likely to have access to loans with lower interest rates, as collateral secures debt (see Kiyotaki and Moore, 1997). Remarkably, the collateral (proxied as the value of illiquid assets) has been insignificant in all specifications, which may reflect the difficulties in terms of the relationship between economic performance and law enforcement during the sample period (see Roland and Verdier 2003). ${ }^{10}$

\footnotetext{
${ }^{8}$ As an informal test of the relevance of instruments for endogenous explanatory variables, we run the "firststage" equations and examine the significance of instruments. In all cases, there were several instruments significant. The resulting R-squared varied substantially. It was about 0.1 for balance sheet indicators and between 0.2-0.9 for variables including the monetary policy interest rate such as the product of the policy rate and small firm dummy (these variables are used in the following sub-section).

${ }^{9}$ In several specifications, the random-effects estimator was consistent, as indicated by a Hausman test. We do not report these results for the sake of brevity. We also re-estimated all the specifications bootstrapping standard errors. In the majority of the specifications, bootstrapped errors were close to asymptotic standard errors. The results are available upon request.

${ }^{10}$ The results with collateral as an explanatory variable are available upon request. Thus, it has been dropped from regressions.
} 
Furthermore, Table 2 confirms that the corporate interest rates are significantly higher during the periods of economic downturns. Small firms also seem to pay higher interest rates, since it is more difficult for lenders to monitor small entities.

Table 2: Determinants of Corporate Interest Rates

\begin{tabular}{|c|c|c|c|c|c|}
\hline & (1) & (2) & (3) & (4) & (5) \\
\hline \multirow[t]{2}{*}{ Net Debt/Assets } & $4.99 * *$ & 2.13 & $3.98 * *$ & $3.98^{*}$ & 2.05 \\
\hline & $(2.15)$ & $(2.78)$ & $(2.11)$ & $(2.11)$ & (2.96) \\
\hline \multirow[t]{2}{*}{ Debt structure } & $-25.1 * *$ & $-21.5^{*}$ & $-26.54 * * *$ & $-26.54 * * *$ & $-22.82 * *$ \\
\hline & $(10.44)$ & (11.5) & (10.04) & (10.04) & $(10.87)$ \\
\hline \multirow[t]{2}{*}{ Cash flow/Assets } & & $-39.13 *$ & & & $-29.63 *$ \\
\hline & & (20.9) & & & $(23.37)$ \\
\hline \multirow[t]{2}{*}{ Downturn } & & & $2.21^{*}$ & & $1.90 *$ \\
\hline & & & $(0.91)$ & & (1.02) \\
\hline \multirow[t]{2}{*}{ Small firms } & & & & $2.22 * *$ & 2.98 \\
\hline & & & & $(0.92)$ & $(10.06)$ \\
\hline Fixed effects & $1.74 * * *$ & $1.36^{* * *}$ & $1.14 * * *$ & $1.86^{* * *}$ & $1.65 * * *$ \\
\hline $\mathrm{R}^{2}$ & 0.01 & 0.02 & 0.01 & 0.01 & 0.08 \\
\hline No. of observations & 1494 & 1494 & 1494 & 1494 & 1494 \\
\hline \multicolumn{6}{|c|}{$\begin{array}{l}\text { Notes: Asymptotic standard errors in parenthesis. Net debt and cash flow are divided } \\
\text { by total assets. } * * *, * * \text {, and } * \text { denote significance level at } 1 \text { percent, } 5 \text { percent, and } \\
10 \text { percent, respectively. See Appendix for the details on the construction of }\end{array}$} \\
\hline
\end{tabular}

\subsection{Financial Accelerator}

Although the dummies for small firms and downturn periods are significant in estimation of (2), this does not necessarily imply that financial accelerator effects are present in the Czech Republic. Both dummies may simply reflect the greater risk of firms during the downturn periods and the greater risk inherent in small firms. For this reason, we turn to the question whether monetary policy effects propagate more strongly to small firms and during the downturns, while we control for balance sheet indicators to proxy the corporate risk. ${ }^{11}$ Thus, we examine whether monetary policy has heterogeneous effects on firms according to firm size. Following the literature (see Bernanke et al., 1999; Mojon et al., 2002), the

\footnotetext{
${ }^{11}$ It is especially important to control for the debt maturity structure as short term debt may obviously react faster than long term debt interest rates. However, we believe that empirically it is not very relevant in our case, because more than $90 \%$ of loans in the Czech economy have a variable interests (i.e. fixed interest rate for less than one year), see CNB (2005).
} 
heterogeneous effects of monetary policy are indicative of financial accelerator phenomenon. Following Mojon et al. (2002), we test for the presence of the financial accelerator in two steps. First, we estimate whether the response to monetary policy effects varies with firm size. Second, we assess whether monetary policy is more powerful during a downturn compared with an upturn. Thus, both equations can be expressed as

$$
\begin{aligned}
& I R_{i t}=\alpha_{1} \frac{D E B T_{i t}}{A_{i t}}+\alpha_{2} \frac{C F_{i t}}{A_{i t}}+\alpha_{3} D S T R_{t t}+\alpha_{4} D O W N_{t}+\alpha_{5} S_{i}+\gamma_{1} R R_{t} S_{i}+\gamma_{2} R R_{t} M_{i}+\gamma_{3} R R_{t} L_{i}+u_{i}+e_{i t} \\
& I R_{i t}=\alpha_{1} \frac{D E B T_{i t}}{A_{i t}}+\alpha_{2} \frac{C F_{i t}}{A_{i t}}+\alpha_{3} D S T R_{t t}+\alpha_{4} D O W N_{t}+\alpha_{5} S_{i}+\delta_{1} R R_{t} D O W N_{t}+\delta_{2} R R_{t} B O O M_{t}+u_{i}+e_{i t}
\end{aligned}
$$

Equation (3) again links the corporate interest rates to the previous balance sheet indicators. In addition to the estimation of (2), we include the product of the yearly average of two-week repurchase rate (the policy rate of the CNB) denoted by $R R$, while $S, M$, and $L$ are dummy variables for the small, medium, and large sized firms (according to assets), respectively. Thus, $R R_{t} S_{i}, R R_{t} M_{i}$, and $R R_{t} L_{i}$ in (3) stand for the product of monetary policy rate and the dummy for the size of firm. It is generally expected that $\gamma_{1}>\gamma_{2}>\gamma_{3}$, that is, that monetary policy effects have the strongest effects on small firms, as compared with the medium and large sized firms (see Mojon et al., 2002).

Similarly, equation (4) assesses whether the effect of monetary policy on the corporate interest rates depends on the business cycle, controlling for the balance sheet indicators. Therefore, we include two variables - the product of $R R$ and $D O W N$, and the product of $R R$ and $B O O M$, where the dummy variable $D O W N$ takes on a unit value if economic growth has been negative in a given year. Conversely, BOOM denotes the dummy variable stating when economic growth has been positive. ${ }^{12}$ In our sample, the Czech Republic recorded negative annual real GDP growth in 1997 and 1998 (-0.8 percent and -1 percent, respectively). The earlier literature suggests that $\delta_{1}>\delta_{2}$. This means that monetary policy is more influential during the downturns (see Gertler and Gilchrist, 1994).

Table 3 documents the heterogeneous impact of monetary policy on firms. Generally, the explanatory variables are significant with the expected signs in all specifications. Moreover, the value of coefficients is typically stable across the specifications, to a large extent. Controlling for the strength of balance sheet indicators, we find that the interest rate level of small firms reacts stronger to monetary policy than those of medium and large firms. The

\footnotetext{
${ }^{12}$ Alternatively, we define the dummies as follows. DOWN and BOOM take a unit value, when the growth in a given year was below and above average, respectively.
} 
coefficient on the product of repo (policy) rate and the small firm dummy is consistently the largest and most precisely estimated coefficient in equation (3). Interestingly, we find no evidence that monetary policy affects the interest rate level of large and medium firms. This may indicate that larger firms still have close ties with the banks. Therefore, monetary policy effects have less impact on these enterprises. In spite of this feature, our results correspond to Vermeulen (2002), who finds that financial accelerator effects are strongest for small firms' investment dynamics in a sample of the four largest euro-area countries. On the contrary, the results of Mojon et al. (2002) do not suggest that monetary policy effects would be stronger for small firms' interest rates than for large firms.

Table 3: Determinants of Corporate Interest Rates, Augmented Estimation

\begin{tabular}{|c|c|c|c|c|c|}
\hline & (1) & (2) & (3) & (4) & (5) \\
\hline \multirow[t]{2}{*}{ Net debt/Assets } & & 0.38 & -0.62 & & -2.87 \\
\hline & & $(1.86)$ & $(2.06)$ & & $(1.87)$ \\
\hline \multirow[t]{2}{*}{ Debt structure } & & $-17.02 * *$ & $-23.36 * *$ & & $-16.08 * *$ \\
\hline & & $(8.73)$ & $(10)$ & & $(7.75)$ \\
\hline \multirow[t]{2}{*}{ Cash flow/Assets } & & -9.37 & -2.93 & & -5.52 \\
\hline & & $(16.73)$ & $(17.31)$ & & $(15.14)$ \\
\hline \multirow[t]{2}{*}{ Repo Rate*Small firm } & $0.77 * *$ & $1.01 * * *$ & $0.90 * *$ & & \\
\hline & $(0.34)$ & $(0.27)$ & $(0.37)$ & & \\
\hline \multirow[t]{2}{*}{ Repo Rate*Medium firm } & 0.14 & & -0.18 & & \\
\hline & $(0.29)$ & & $(0.33)$ & & \\
\hline \multirow[t]{2}{*}{ Repo Rate*Large firm } & 0.11 & & 0.61 & & \\
\hline & $(0.31)$ & & $(0.44)$ & & \\
\hline \multirow[t]{2}{*}{ Repo Rate*Recession } & & & & $0.29 * * *$ & $0.5^{* * *}$ \\
\hline & & & & $(0.09)$ & $(0.12)$ \\
\hline \multirow[t]{2}{*}{ Repo*Boom } & & & & $0.36 * *$ & $0.75^{* * *}$ \\
\hline & & & & $(0.17)$ & $(0.22)$ \\
\hline Fixed effects & $2.52 * *$ & $2.33 * * *$ & $2.37 * * *$ & $2.64 * * *$ & $2.93 * * *$ \\
\hline $\mathrm{R}^{2}$ & 0.03 & 0.07 & 0.08 & 0.02 & 0.12 \\
\hline No. of observations & 1494 & 1494 & 1494 & 1494 & 1494 \\
\hline
\end{tabular}

Note: See Table 2.

Table 3 also displays the results on the asymmetric effect of monetary policy over the business cycle. There are several studies investigating the asymmetry of monetary policy effects. Using Austrian data for the period from 1976 to 1998, Kaufmann (2002) finds that monetary policy effects are indeed asymmetric over the business cycle. Similarly, Peersman 
and Smets (2005) find the asymmetric impact of monetary policy on industrial production in the euro area countries.

Contrary to the findings reported for other countries, our results do not suggest that monetary policy is more efficient during the downturns. Actually, we can see that monetary policy effects might be stronger during the boom period, although the coefficients are not statistically different. In our opinion, the lack of asymmetric effects of monetary policy may reflect the specific conditions at the Czech credit market during the economic reforms of the 1990s. The market was characterized by rather soft budget constraints at the outset of economic transition and subsequent credit rationing at the end of the 1990s (see Hampl and Matousek, 2000).

We also examine the heterogeneous impact of monetary policy depending on credit conditions. When credit conditions are tight, it is likely that small policy changes trigger a greater reaction in corporate interest rates than otherwise. We identify tight credit conditions using the results of Pruteanu (2004). Pruteanu finds that the period from 1999 to 2000 can be characterized as credit rationing in the Czech Republic. Her empirical results suggest that moderate excess demand for bank loans existed then. She argues that excess demand has been a consequence of the downturn in 1997 and 1998 and of continuing instability in the banking sector. Following economic recovery, the demand for loans increased, although this was not followed by sufficient growth in the loan supply given the lack of improvement in issues related to very high level of bad loans in the Czech banking sector. Indeed, our results suggest that monetary policy has significantly stronger effects on corporate interest rates between 1999 and 2000, but we admit that these results depend crucially on the identification of credit rationing by one particular paper. Therefore, they are available upon request.

\section{Conclusions}

We examine the determinants of the corporate interest rates using a panel data set based on financial statements from Czech firms between 1996 and 2002. Specifically, we assess the relationship between a firm's financial position and the cost of external financing. In addition, we examine whether monetary policy has heterogeneous effects on firms according to their size and whether the response to monetary policy effects depends on the business cycle. Examining the heterogeneity of monetary policy effects allows us to assess the presence of financial accelerator effects in the Czech economy.

Overall, the results suggest that balance sheet indicators are vital determinants of the 
corporate interest rates. We find that debt maturity structure is especially robust, while other leverage and liquidity indicators are significant in several specifications. In addition, the strength of balance sheet indicators seems to vary with the firm size. We also find certain evidence of the heterogeneous impact of monetary policy effects. Monetary policy has stronger effects on smaller firms than on medium and large sized firms. However, we do not find any evidence that monetary policy effects depend on the business cycle in the Czech Republic.

All in all, our results indicate that balance sheet indicators affect the corporate interest rates and that monetary policy effects propagate unequally across firms. The latter finding suggests some support for the existence of financial accelerator effects in our data set. In turn, we also find that the Czech transmission mechanism differs from the structure reported for developed economies, possibly reflecting that the importance of loans is lower in the Czech Republic than in mature market economies (EBRD, 2005). This may cause some difficulties during the adoption of the euro. Especially during recession periods or a period of monetary tightening, Czech firms may respond less to the common monetary policy of the European Central Bank than the firms in other countries. Nevertheless, the structure of the monetary transmission mechanism is likely to converge to those in other countries.

\section{References}

Angeloni, I.; A. Kashyap; and B. Mojon. 2003. Monetary Policy Transmission in the Euro Area, Cambridge University Press, Cambridge.

Ball, L.; and G. Mankiw. 1994. "Asymmetric Price Adjustment and Economic Fluctuations." Economic Journal 104: 247-61.

Benito, A.; and J. Whitley. 2003. "Implicit Interest Rates and Corporate Balance Sheets: An Analysis Using Aggregate and Disaggregated UK Data.” Working Paper No. 193, Bank of England, London.

Berg, C.; J. Hansen; and P. Sellin. 2004. "The Financial Accelerator and Corporate Investment." Sveriges Riksbank Economic Review 2: 23-46.

Bernanke, B.S.; and M. Gertler. 1989. "Agency Cost, Net Worth and Business Fluctuations.” American Economic Review 79: 14-31.

Bernanke, B.S.; M. Gertler, and S. Gilchrist. 1999. "The Financial Accelerator in a Quantitative Business Cycle Framework." in Handbook of Macroeconomics, Volume 1 (Eds.) J. Taylor and M. Woodford, North Holland, Amsterdam.

Boissay, F. 2001. "Credit Rationing, Output Gap and Business Cycles.” Working Paper No. 
87, European Central Bank, Frankfurt am Main.

Bougheas, S.; P. Mizen; and C. Yalcin. 2006. "Access to External Finance: Theory and Evidence on the Impact of Firm-Specific Characteristics." Journal of Banking and Finance 30: $199-227$.

Calstrom, C.; and T. Fuerst. 1997. "Agency Costs, Net Worth and Business Fluctuations: A Computable General Equilibrium Analysis.”American Economic Review 87: 893-910.

Coricelli, F.; B. Égert; and R. MacDonald. 2006. "Monetary Transmission Mechanism: Gliding on a Wind of Change.” Discussion Paper No. 8/2006, Bank of Finland, BOFIT, Helsinki.

CNB. 2005. Financial Stability Report 2005, Czech National Bank, Prague.

Dhyne, E.; L. Alvarez; H. Le Bihan; G. Veronese; D. Dias; J. Hoffmann; N. Jonker; P. Lunnemann; F. Rumler; and J. Vilmunen. 2006. "Price Setting in the Euro Area: Some Stylized Facts from Individual Consumer Data." Journal of Economic Perspectives 20: 171-192.

EBRD. 2005. Transition Report 2005, Business in Transition, EBRD, London.

Elbourne, A.; J. de Haan. 2006. "Financial Structure and Monetary Policy Transmission in Transition Countries." Journal of Comparative Economics 34: 1-23.

Fidrmuc, J. 2008. "Money Demand and Disinflation in Selected CEECs.” Applied Economics, forthcoming.

Fidrmuc, J.; C. Hainz; and A. Malesich. 2006. "Default Rates in the Loan market for SMEs: Evidence from Slovakia.” Working Paper No. 854, William Davidson Institute, University of Michigan.

Fidrmuc, J.; and I. Korhonen. 2006. "Meta-Analysis of the Business Cycle Correlation between the Euro Area and the CEECs.” Journal of Comparative Economics 34: 518-537.

Gazioglu, S.; W. D. McCausland. 2008. "Interest Rates and Monetary Policy." Applied Economics, forthcoming.

Gertler, M.; and S. Gilchrist. 1993. "The Role of Credit Market Imperfections in the Monetary Transmission Mechanism: Arguments and Evidence." Scandinavian Journal of Economics 95: 43-64.

Gertler, M.; and S. Gilchrist. 1994. "Monetary Policy, Business Cycles and the Behavior of Small Manufacturing Firms." Quarterly Journal of Economics 109: 309-40.

Hanousek, J.; and R. Filler. 2004. "Investment, Credit Rationing, and the Soft Budget Constraint: What Would a Well-Functioning Credit Market Look Like? Economics Letters 82: 385-90. 
Hampl, M.; and R. Matousek. 2000. "Credit Contraction in the Czech Republic: The Causes and Consequences.” Working Paper No. 19, Czech National Bank, Prague.

Kashyap, A.; O. Lamont; and J. Stein. 1994. "Credit Conditions and the Cyclical Behavior of Inventories.” Quarterly Journal of Economics 109: 565-592.

Kaufmann, S. 2002. "Is there an Asymmetric Effect of Monetary Policy over Time? A Bayesian Analysis Using Austrian Data.” Empirical Economics 27: 277-97.

Kiyotaki, N.; and J. Moore. 1997. "Credit cycles.” Journal of Political Economy 105: 211248.

Konings, J.; M. Rizov; and H. Vandenbusche. 2003. "Investment and Financial Constraints in Transition Economies: Micro Evidence from Poland, the Czech Republic, Bulgaria and Romania." Economics Letters 78: 253-8.

Kotlan, V.; and D. Navratil. 2003. "Inflation Targeting as a Stabilization Tool: Its Design and Performance in the Czech Republic." Finance a úvěr - Czech Journal of Economics and Finance 53: 220-242.

Lizal, L. 1999. "Depreciation Rates in Transition Economy: Evidence from Czech Panel Data." Prague Economic Papers 8: 261-76.

Lizal, L.; and J. Svejnar. 2002. "Investment, Credit Rationing and the Soft Budget Constraint: Evidence from Czech Panel Data" Review of Economics and Statistics 84: 353-70.

Mojon, B.; F. Smets; and P. Vermeulen. 2002. "Investment and Monetary Policy in the Euro Area." Journal of Banking and Finance 26: 2111-29.

Moons, C.; and A. Van Poeck. 2008. "Does One Size Fit All? A Taylor-Rule Based Analysis of Monetary Policy for Current and Future EMU Members." Applied Economics 40: 193199.

Nerlove, M. 2002. "Properties of Alternative Estimators of Dynamic Panel Models: An Empirical Analysis of Cross-Country Data for the Study of Economic Growth." in Essays in Panel Data Econometrics (Ed.) M. Nerlove, Cambridge University Press, Cambridge.

Oliner, S.; G. Rudebush. 1996. "Is there a Broad Credit Channel of Monetary Policy?" Federal Reserve Board of San Francisco Economic Review 1: 3-13.

Peersman, G.; and F. Smets. 2005. "The Industry Effects of Monetary Policy in Euro Area." Economic Journal 115: 319-42.

Pruteanu, A. 2004. "Was there Evidence for Credit Rationing in the Czech Republic?" Eastern European Economics 42: 58-72.

Pruteanu-Podpiera, A. 2007. "The Role of Banks in the Czech Monetary Policy Transmission Mechanism." Economics of Transition 15: 393-428. 
Roland, G.; T. Verdier. 2003. "Law Enforcement and Transition." European Economic Review 47: 669-85.

Schmitz, B. 2004. "What Role do the Banks Play in Monetary Policy Transmission in EU New Member Countries?” University of Bonn. Mimeo.

Vermeulen, P. 2002. "Business Fixed Investment: Evidence of a Financial Accelerator in Europe." Oxford Bulletin of Economics and Statistics 64: 213-31. 


\section{Appendix: Construction of Variables}

- $I R_{i t}$ - corporate interest rate for $i$-th firm at time $t, I R_{i t}=I N R E X_{i t} / T D E B T_{i t}$. $I N R E X_{i t}$ are interest expenses from the profit-loss account, and total debt $\left(T D E B T_{i t}\right)$ is a sum of fixed liabilities and bank loans and borrowings from the balance sheet.

- $D_{S T R_{i t}}$ - debt structure measured as 1 minus the ratio of short-term debt to total company debt. Short-term debt is the current liabilities from balance sheets. Total company debt is calculated as the sum of current liabilities, fixed liabilities, bank loans and borrowings from balance sheets. This proxy estimates the extent of shortterm financing.

- $D E B T_{i t}$ - net debt of the company defined as total debt less cash and cash equivalents.

- $C F_{i t}$ - cash flow, generated by the firm is calculated as the sum of the depreciation of the tangible and the intangible assets and the net income from profit-loss accounts.

- $C O L L_{i t}$ - collateral value of illiquid assets. We first estimate the depreciation rate as follows: DEPRECIATION ${ }_{i t}=\alpha+\beta$ CAPITAL $_{i t}+e_{i t}$, where DEPRECIATION Dit $_{i t}$ is depreciation of tangible and intangible fixed assets from profit-loss accounts, and CAPITAL $_{i t}$ is a sum of tangible and intangible fixed assets from the balance sheets. Having estimated the above equation by the fixed-effects estimator, the results indicate that annual depreciation rate is 8.3 percent (a simple ordinary-least-squares regression yields a value of 8.4 percent). This rate is somewhat higher than findings reported by Lizal (1999). Lizal, using comparable methodology, estimates the annual rate of depreciation between 4.8 and 5 percent. Some of his alternative specifications lead to an estimate of annual depreciation of about 6.3 percent. The data used in Lizal's paper are from the period 1992-95, which may explain the difference in the results. Nevertheless, our result is consistent with the Czech accounting standards since the depreciation rate may legally range between 2 and 20 percent. Controlling for industry effects influences the estimated depreciation only minimally. As a result, we work with a depreciation rate of 8 percent when deriving the value of collateral. In this regard, the estimated rate of depreciation is used to compute the collateral value of illiquid assets as: $C O L L_{i t}=I_{i t}+(1-\delta) K_{i t-1}$, where $C O L L_{i, t}$ is the collateral value of illiquid assets in $i$-th firm at time $t, I_{i, t}$ is $i$-th firms' investment at time $t, K_{i t-1}$ is a booked value of illiquid assets at time $t-1$, and $\delta$ is the rate of depreciation as 
computed above. As $I_{t}=K_{t}-K_{t-1}$, the value of collateral is computed finally as follows: $C O L L_{i t}=K_{i t}-\delta K_{i t-1}$.

- $\quad D O W N_{t}$ - dummy, which equals 1 when GDP y-o-y growth is negative (i.e., 1997 and 1998 in our sample) and 0 otherwise. Analogously, the $\mathrm{BOOM}_{t}$ dummy has zero value when y-o-y growth is positive.

- $\quad R R_{t} S_{i}, R R_{t} M_{i}$, and $R R_{t} L_{i}$ - product of the annual average of two-week repurchase rate of the CNB and dummy variables for small, medium-, and large-sized firms, respectively. The $S_{i}$ dummy takes a value of 1 when the firm's assets are smaller than the $33^{\text {rd }}$ percentile of the sample. The $M_{i}$ dummy takes a value of 1 when firm's assets are between the $33^{\text {rd }}$ and $66^{\text {th }}$ percentiles. The $L_{i}$ dummy is 1 when firm's assets lies above $66^{\text {th }}$ percentile.

- $A I R_{t}$ - the weighted aggregate interest rate is used for comparison with the sample corporate interest rates (see Chart 1). The volume of debt outstanding weights the maturity structure of the interest rate for each maturity as follows:

$$
A I R_{i t}=\frac{s t_{i t}}{s t_{i t}+m t_{i t}+l t_{i t}} s i r_{i t}+\frac{m t_{i t}}{s t_{i t}+m t_{i t}+l t_{i t}} m i r_{i t}+\frac{l t_{i t}}{s t_{i t}+m t_{i t}+l t_{i t}} l i r_{i t} \text {, }
$$

where $A I R_{t}$ stands for the representative aggregate interest rate, $s t_{t}$ for the amount of short-term debt outstanding, $m t_{t}$ for the amount of mid-term debt outstanding a, $l t_{t}$ for the amount of long-term debt outstanding, $s i r_{t}$ for the short-term average interest rate paid by firms, mir $_{t}$ for the mid-term average interest rate paid by firms, and $l i r_{t}$ is the long-term average interest rate paid by firms. We use data on the monthly interest rates on loan balances and the monthly statements on loans and receivables from clients, as collected by the Czech National Bank. Short-term instruments are those labelled with maturities of less than one year, medium-term instruments have maturities between one and five years, and long-term instruments maturities over five years. The data period is from January 1996 to December 2002. 